\title{
MATHEMATICA APPLICATION FOR GRAPH COLORING AT THE INTERSECTION OF JALAN PANGERAN ANTASARI JAKARTA
}

\author{
Suwarno \\ Universitas Bina Nusantara \\ E-mail: suwarno001@binus.ac.id
}

\begin{abstract}
This research examines about graph coloring using Welch-Powell algorithm. This research begins by trying to understand about graph coloring and its algorithm. The case study was conducted at the intersection of Pangeran Antasari Street. In the formation of graph obtained 12 vertices as traffic flow and 16 edges as traffic path. The results of this study obtained 4 chromatic numbers which describes 4 stages of traffic light arrangement. This paper also explains the application of Mathematica software in graph coloring.
\end{abstract}

Keywords: Vertex coloring, Welch-Powell, Chromatic number, Mathematica

\section{PRELIMINARY}

As a city entitled as the most populous city in the world, Jakarta has many problems. One of the problems is in terms of traffic management. The increasing population of Jakarta resulted in an increasing number of operating vehicles daily. As a result, there is a density of traffic flows, especially on arterial roads that are often bypassed. The density of traffic flows often leads to vehicles buildup at the crossroads.

One of the intersections that often experience crowded is the intersection of Jl. Pangeran Antasari, Jl. Pelita Abdul Majid, and Jl. Abdul Majid Raya. Figure 1 illustrates the problem of the buildup of the number of vehicles.

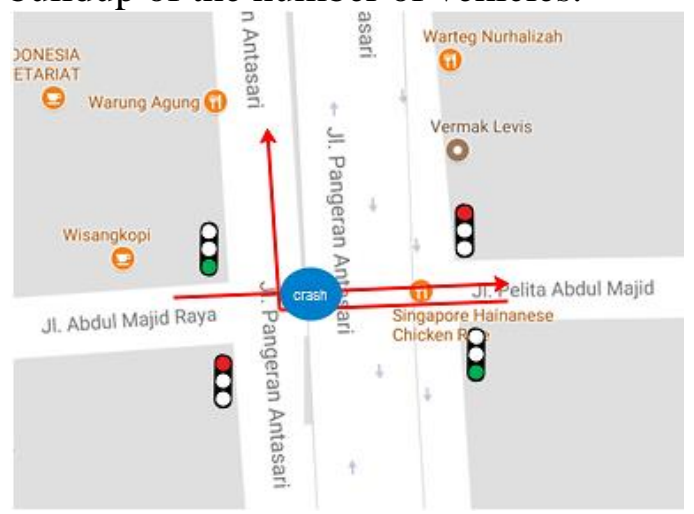

Figure 1. Illustration of J1. Pangeran Antasari Intersection
The problem that occurred at the intersection is the green light on $\mathrm{Jl}$. Abdul Majid Raya lit up along with the green light which is on Jl. Pelita Abdul Majid. This resulted in the flow of traffic from the direction of $\mathrm{Jl}$. Abdul Majid Raya to Jl. Pelita Abdul Majid crashes with traffic flow from Jl. Pelita Abdul Majid to Jl. Pangeran Antasari (heading to Blok M). Things like this happen every day. Vehicles from two different traffic streams are scrambling to precede each other. As a result there is accumulation of vehicles in the middle of the intersection of $\mathrm{Jl}$. Pangeran Antasari.

Some of the scientific studies that have been done in overcoming traffic lights problems include setting traffic lights at the intersection of jalan Ahmad Yani Giant (Diana, Suryaningtyas, \& Suprapti, 2016), Welch-Powell algorithm for traffic light control (Purnamasari, Ilman, \& P, 2012), Graph coloring application Fuzzy to classify traffic lanes at the intersection of jalan Insinyur Soekarno Surabaya (Sulastri, Darmaji, \& Irawan, 2014), and nodes coloring with Welch-Powell algorithm 
on traffic light at Yogyakarta (Soimah \& Mussafi, 2013).

In this research, the traffic light setting is designed using Welch-Powell algorithm. Welch-Powell algorithm is one way of graph coloring to overcome scheduling problems. Welch-Powell algorithm is also included in the Greedy algorithm, an algorithm which each completion step has more than one completion. In this study, the WelchPowell algorithm was made using Mathematica programming language.

\section{Graph Definition (Munir, 2007)}

Graph $G$ is defined as the $(V, E)$ pair of sets, written with $G$ notation $G=(V, E)$, in which case $V$ is the nonempty set of vertices and $E$ is set of edges connecting a pair of vertices, $E$ cannot be empty. A graph that has only a side without a side is called a trivial graph. The $G$ graph below consists of 7 vertices and 13 sides.

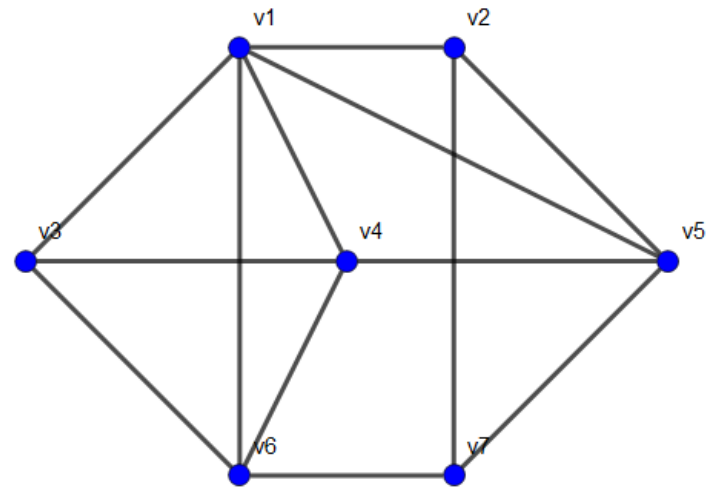

Figure 2. Graph G Example

\section{Graph Node Coloring (Rosen, 2012)}

Simple graph coloration is a way of giving color to each vertex of the graph so that no two adjacent vertices have the same color. The graph can be colored by assigning different colors to each of its vertices. However, in most graph colorings it can be found that the use of colors is less than the number of vertices in the graph. The example of graph coloring is shown in the figure below.

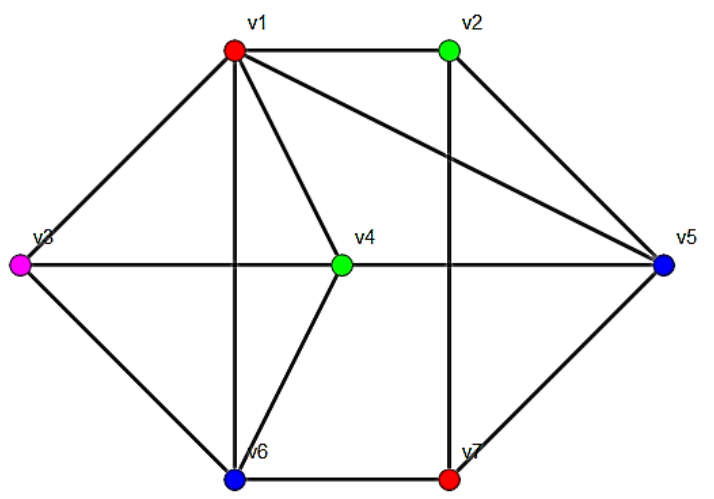

Figure 3. Graph Coloring Example

Chromatic Numbers (Koh, Dong, Ng, \& Tay, 2015)

For instance, $G$ is a graph. The chromatic number of graph $G$ is denoted by $\chi(G)$ is the minimum number of colors used to color the vertices in graph $G$ so that adjacent nodes are colored with different colors. The graph in Figure 3 has a chromatic number $\chi(G)=4$.

\section{Welch-Powell Algorithm (Munir, 2007)}

Welch-Powell algorithm is an algorithm used to color the vertices of a graph based on the highest degree of the vertices. The steps of Welch-Powell algorithm are described as follows.

1. Sort the vertices of graph $G$ in decreasing degrees (this sequence may not be unique Because some vertices may have the same degree).

2. Use one color for the first high-level node and the other nodes (in sequential order) that are not next to this first node.

3. Start again with the next highest degree node in the un-colored sequence list and repeat the node coloring process using the second color.

4. Repeat the color addition until all the nodes have been colored. 


\section{RESEARCH METHODOLOGY}

The method in this research is literature study by reading and understanding the concept of graph coloring to solve the problem of traffic arrangement. The steps used in this study are as follows.

\section{Data Collection}

Data collection is done through direct observation to obtain primary data. Direct observation is done at the intersection of Jl. Pangeran Antasari, Jl. Pelita Abdul Majid, and Jl. Abdul Majid Raya. Those three are located at South Jakarta area. Based on the observations the following data is obtained.

1. Intersection image of Jl. Pangeran Antasari, Jl. Pelita Abdul Majid, and Jl. Abdul Majid Raya. This data is used to identify the problem of meeting two traffic flows from $\mathrm{Jl}$. Abdul Majid Raya towards Jl. Pelita Abdul Majid with traffic flow from J1. Pelita Abdul Majid towards J1. Pangeran Antasari (heading to Blok M).

2. Traffic flow intersection from $\mathrm{Jl}$. Pangeran Antasari was obtained from field observations. This data is used to determine the nodes in the graph.

\section{Problem Solving}

Problem solving is done by determining chromatic number of graph. Graph coloring was performed using the Welch-Powell algorithm. The Welch-Powell algorithm is created using the Mathematica programming language. The obtained chromatic number is the solution of the problem of meeting two traffic flows so that no more vehicles from two traffic flows meet at the center of the intersection of Jl. Pangeran Antasari.

\section{RESEARCH RESULT AND DISCUSSION}

Determining the location of the research object is the first step in this study. The study was conducted at the intersection of Jl. Pangeran Antasari, Jl. Pelita Abdul Majid, and Jl. Abdul Majid Raya. Here is the location of the research object.

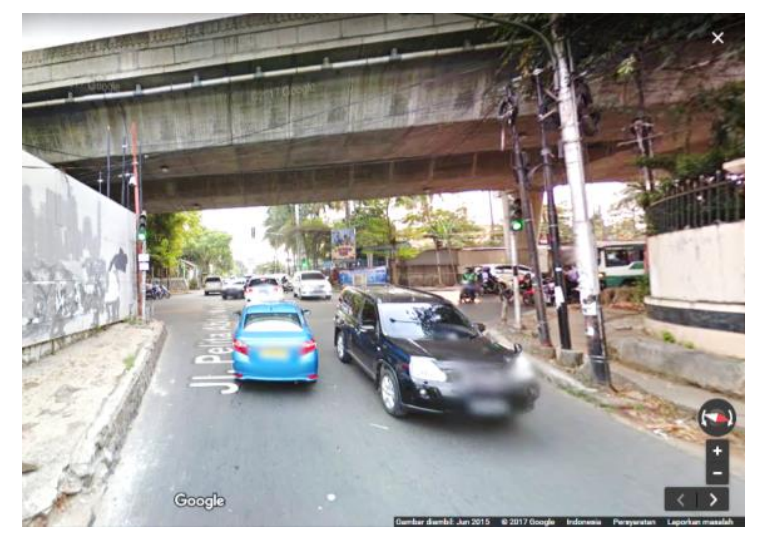

Figure 4. Location of Research Object

Furthermore, the application of graph coloring is done to determine the flow of traffic that describes the condition of the research object. The intersection image is then converted into graph.

\section{Traffic Flow System}

Initial observations were made to determine the number of passes allowed to cross the crossroads and to determine passable passes. The observed data is the traffic flow data of two-wheeled and four-wheeled vehicles with the assumption that there are no crossers. Based on these observations, the traffic system applied at the crossroads is shown in the figure below. 
ISSN 2089-8703 (Print) Vol. 6, No. 2 (2017)

ISSN 2442-5419 (Online)

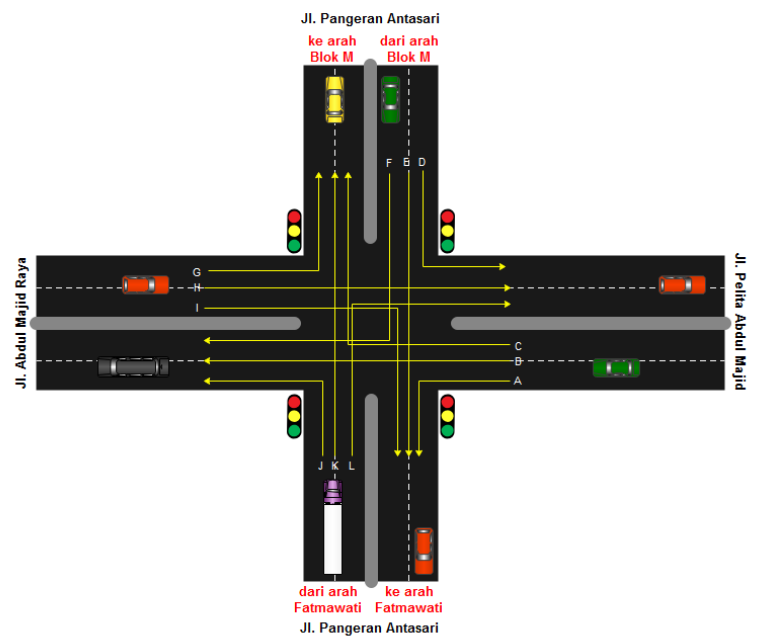

Figure 5. Traffic Flow Illustration

In the picture above there are several paths as follows:

A: Jl. Pelita Abdul Majid towards Jl. Pangeran Antasari (heading to Fatmawati)

B: Arah Jl. Pelita Abdul Majid towards Jl. Abdul Majid Raya

C: Arah Jl. Pelita Abdul Majid towards Jl. Pangeran Antasari (heading to Blok M)

D: Arah Jl. Pangeran Antasari (from Blok M) towards Jl. Pelita Abdul Majid

E: Arah Jl. Pangeran Antasari (dari arah Blok M) towards Jl. Pangeran Antasari (heading to Fatmawati)

F: Arah Jl. Pangeran Antasari (from Blok M) towards Jl. Abdul Majid Raya

G: Jl. Abdul Majid Raya towards Jl. Pangeran Antasari (heading to Blok M)

H: Jl. Abdul Majid Raya towards Jl. Pelita Abdul Majid

I: J1. Abdul Majid Raya towards u Jl. Pangeran Antasari (heading to Fatmawati)

J: Jl. Pangeran Antasari (from Fatmawati) towards Jl. Abdul Majid Raya
K: Jl. Pangeran Antasari (from Fatmawati) towards J1. Pangeran Antasari (heading to Blok M)

L: Jl. Pangeran Antasari (from Fatmawati) towards J1. Pelita Abdul Majid

\section{Graph Formation}

Traffic flow system at the $\mathrm{Jl}$. Pangeran Antasari intersection was transformed into graph form as follows.

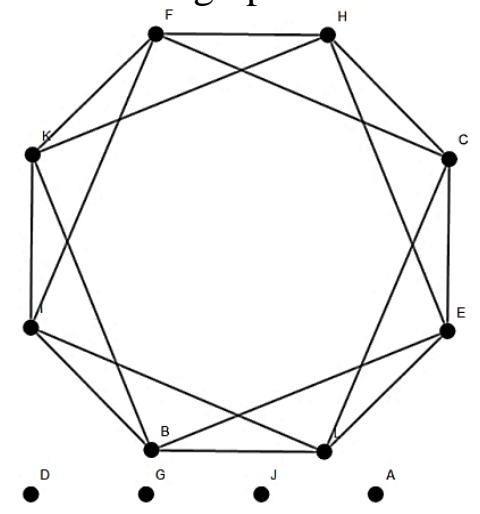

Figure 6. Jl. Pangeran Antasari Intersection Graph

Based on the graph above, it is known node $\mathrm{A}, \mathrm{D}, \mathrm{G}$, and $\mathrm{J}$ are foreign nodes that are not connected with other nodes. It can be said that the vehicles flow declared with nodes A, D, G, and J 
can run in tandem with the other vehicles flow.

Since the vertices A, D, G, and J are vertices that are not connected to another node, they can be removed so that the graphic form is shown below.

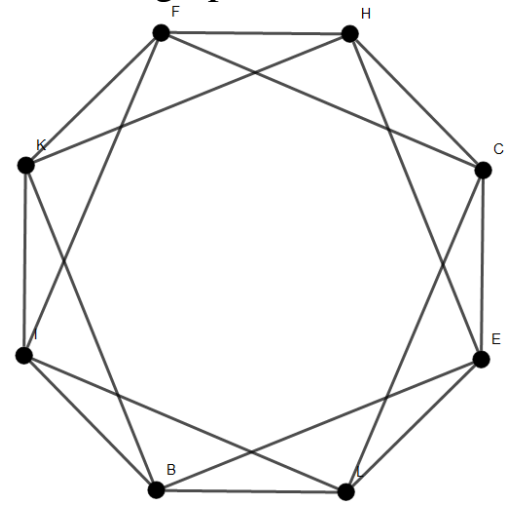

Figure 7. Graph Intersection of $\mathrm{Jl}$. Pangeran Antasari after the nodes A, D, $\mathrm{G}$, and $\mathrm{J}$ are removed

\section{Graph Coloring}

The graph coloration on this problem uses the Welch-Powell algorithm in determining chromatic numbers. Based on Welch-Powell algorithm the result is as follows.

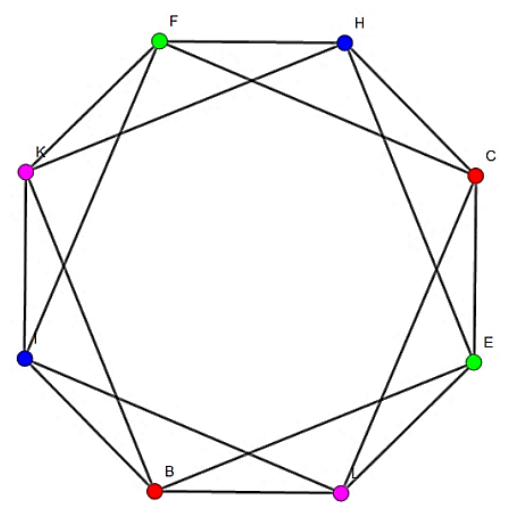

Figure 8. The Result of Jl. Pangeran Antasari Intersection Graph Coloring

From the result of coloring the graph above the chromatic number is $\chi(G)=4$. The solution of the flows that can run together simultaneously are shown in Table 1 below.
Table 1. Jl. Pangeran Antasari Intersection Graph Color

\begin{tabular}{|c|c|}
\hline Color & Node \\
\hline Blue & H, I \\
\hline Red & B, C \\
\hline Purple & K, L \\
\hline Green & E, F \\
\hline
\end{tabular}

Based on Table 1, there are four stages of traffic light arrangement as follows.

1. The First Stage

The traffic flow $\mathrm{H}$ goes along with the traffic flow I. That is, vehicles that can go when the green light is lit are the vehicles from Jl Abdul Majid Raya towards Jl. Pelita Abdul Majid dan and vehicles from $\mathrm{Jl}$. Abdul Majid Raya towards $\mathrm{Jl}$. Pangeran Antasari (heading to Fatmawati).

2. The Second Stage

The traffic flow B goes along with the traffic flow C. That is, the vehicles that can go at the time of the green light is lit are vehicles from Jl Pelita Abdul Majid to Jl. Abdul Majid Raya and vehicles from Jl. Pelita Abdul Majid to Jl. Pangeran Antasari (heading to Blok M).

3. The Third Stage

Traffic flow $\mathrm{K}$ goes along with traffic flow L. That is, the vehicle that can go at the time of the green light is lit are vehicles from Jl Pangeran Antasari (from Fatmawati) to Jl. Pangeran Antasari (heading to Block $\mathrm{M}$ ) and vehicles from Jl Pangeran Antasari (from Fatmawati) to Jl. Pelita Abdul Majid.

4. The Fourth Stage

Traffic flow E goes along with traffic flow F. That is, the vehicles that can run at the time of the green light is lit are vehicles from Jl Pangeran Antasari (from Blok M 
ISSN 2089-8703 (Print) Vol. 6, No. 2 (2017)

ISSN 2442-5419 (Online)

direction) to Jl. Pangeran Antasari (heading to Fatmawati) and vehicles from Jl. Pangeran Antasari (from Blok M) to Jl. Abdul Majid Raya.

\section{Mathematica Programming}

Mathematica is one of the advanced Computer Algebra System (CAS) today. Its first version was released in 1988 by Wolfram Research. Since then it has continued to grow with over twenty versions published by Wolfram Research. Mathematica system works with input-output logic, has graphical interface, and easy to be used to create graphic (Ardic \& Isleyen, 2017). Here is the Mathematica program code for graph coloring.

1. Program code for color determination.

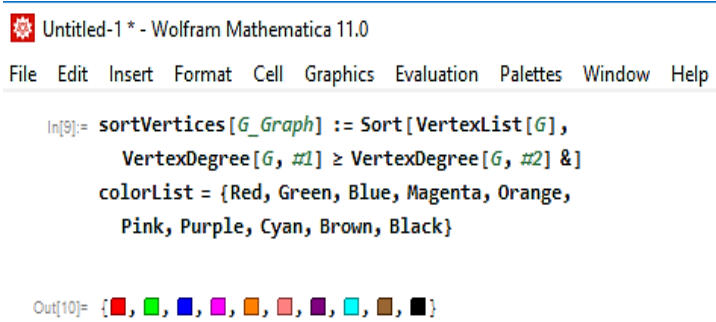

2. Program code for Welch-Powell algorithm.

$\ln [5] ;=$ greedyColorer:: colorx = "Insufficiently many colors."

greedyColorer [G_Graph] := Module [ $\{H=G, V$, currentColor, excludeSet, $i\}$, $\mathrm{V}=$ sortVertices $[\mathrm{H}] \mathbf{j}$

For [currentColor $=1$, currentColor $\leq$ Length [colorList], currentColor ++, PropertyValue $[\{H, V[[1]]\}$, Vertexstyle] = colorList [ [currentColor]]; excludeSet $=$ VertexList $[$ NeighborhoodGraph $[H, V[[1]]]]$; $\mathrm{V}=$ Delete $[\mathrm{V}, \mathbf{1}] \mathbf{j}$

While $[\hat{i} \leq$ Length [V],

If [ I MemberQ [excludeset, v[[i]]],

PropertyValue $[\{\mathrm{H}, \mathrm{V}[[\mathrm{i}]]\}$, VertexStyle $]=$

colorList [ [currentColor] ] ;

excludeset $=$ Union [ excludeSet,

VertexList [NeighborhoodGraph [H, V[[i]]]]];

$v=\operatorname{Delete}[v, i]$,

i++

]

];

If $[\mathrm{V}=\{\}$, Break []$]$

];

If $[\mathrm{V} \neq\{\}$,

Message [greedyColorer: : colorx]; Return [\$Failed], H]
3. Program code for graph formation

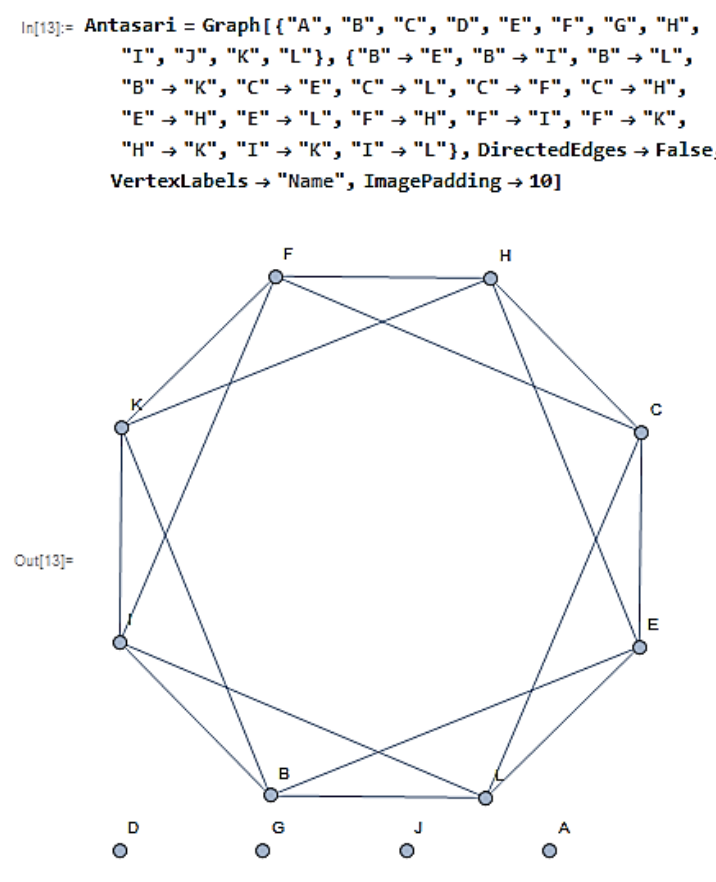

4. Program code for graph coloring

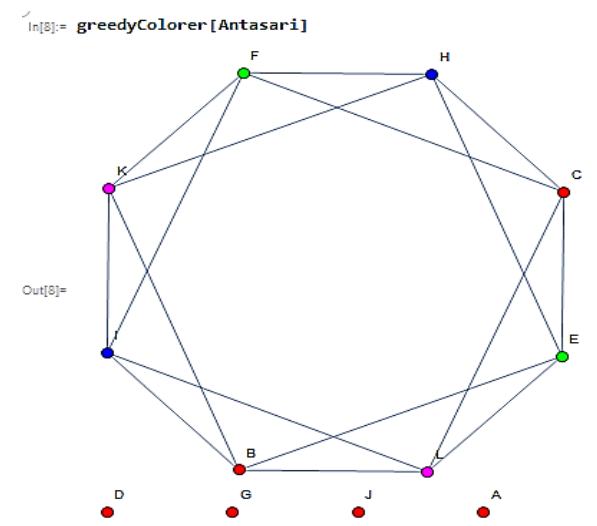

\section{CONCLUSIONS RECOMMENDATIONS}

AND

Based on the research that has been done, some conclusions are obtained as follows.

1. Welch-Powell algorithm can be applied to solve the problem of traffic flow arrangement at the intersection of $\mathrm{Jl}$. Pangeran Antasari. The step needed is by 
transforming the traffic flow at the intersection of Jl. Pangeran Antasari into graph. Furthermore, coloring the graph nodes using Welch-Powell algorithm to determine which traffic flow could go together.

2. From the graph coloring, chromatic number $\chi(G)=4$ was obtained. Jl. Pangeran Antasari intersection case resulted 4 steps of traffic flows. The current $\mathrm{H}$ goes along with traffic flow I, current B goes with traffic C, traffic flow $\mathrm{K}$ goes with traffic flow $\mathrm{L}$, and current $\mathrm{E}$ runs with current $\mathrm{F}$. Nodes A, D, G, and $\mathrm{J}$ are not connected with other vertices so they can run in along with the flow of other vehicles

As for suggestion, this research needs to do further research by paying attention to waiting time at every traffic light. Waiting time data can be obtained by direct observation or through the data of Jakarta Transportation Department.

\section{BIBLIOGRAPHY}

Ardic, Mehmet A., Isleyen, T., (2017). Secondary School Mathematics Teachers' and Students' Views on Computer Assisted Mathematics Instruction in Turkey: Mathematica Example. Malaysian Online Journal of Educational Technology. 5(1), 46-64.

Diana, Erna L., Suryaningtyas, W., \& Suprapti, E. (2016). Pengaturan Lampu Lalu Lintas Di Persimpangan Jalan Ahmad Yani Giant Dengan Aplikasi Pewarnaan Teori Graf. Journal of Mathematics Education, Science and Technology, 1(1), 69-85.

Koh, K. M., Dong, F., Ng, K. L., \& Tay, E. G. (2015). Graph Theory Undergraduate Mathematics. Singapore: World Scientific
Publishing Co. Pte. Ltd.

Munir, Rinaldi. (2007). Matematika Diskrit. Bandung: Informatika.

Purnamasari, D., Ilman, M. Z., \& P, D. W. A. (2012). Algoritma WelchPowell untuk Pengendalian Lampu Lalu Lintas. UG JURNAL, 6(3), 26-33.

Rosen, K. H. (2012). Discrete mathematics and its applications. (M. Lange, B. Stenquist, L. K. Buczek, \& R. Kernan, Eds.), New York (seventh). New York: Mc Graw Hill.

Soimah, A. M., \& Mussafi, N. S. M. (2013). Pewarnaan Simpul Dengan Algoritma Welch-Powell Pada Traffic Light di Yogyakarta. FOURIER, 2(2), 87-96.

Sulastri, Darmaji, \& Irawan, M. I. (2014). Aplikasi Pewarnaan Graf Fuzzy untuk Mengklasifikasi Jalur Lalu Lintas di Persimpangan Jalan Insinyur Soekarno Surabaya. Jurnal Sains Dan Seni POMITS, 3(2), A10-A15. 